\title{
Development of a Future Orientation Model in Emerging Adulthood in Hungary
}

\author{
Zsuzsánna E. Horváth ${ }^{1}$, Erzsébet Nováky ${ }^{2 *}$ \\ ${ }^{1}$ University of Southern Queensland, School of Linguistics, Adult and Specialist Education, West Street, \\ Toowoomba Qld 4350, Australia. \\ ${ }^{2}$ Corvinus University of Budapest, Department of Human Geography and Sustainable Development, Fövám tér 8 , \\ 1093 Budapest, Hungary.
}

KEYWORDS

Concern

Future orientation

Norms

Predictive modelling

Values

\section{A BSTRACT}

Social and economic sustainability of countries globally largely depend on how well educational structures are capable of empowering future generations with skills and competencies to become autonomous and active citizens. Such competency is future planning, which is vital in the identity formation of youth in their developmental phase of emerging adulthood. The article below attempts to elaborate a predictive model of future orientation based on current and future norms, future interest and concern. The model was tested on a sample population of business school students $(N=217)$ in their emerging adulthood. Norm acceptance ranking proved to be different for present and future times. Amongst a number of contextual variables shaping the formation of future plans concern has been found to hold the strongest predictive power.

\section{Introduction}

The purpose of this paper was to elaborate a complex predictive model of future interest of students, based on their assessment of current and future values and the contextual variables responsible for the formation of these value systems. The model draws on the time shift in the focus of value systems from the current educational environment to the students' prospect

\footnotetext{
* Contact address: zsenilia1@gmail.com (Z. E. Horváth)
} 
(professional or other) life beyond. The model has been developed following a set of hypotheses, each targeting the predictive relationships between students' contextual variables (both institutional and private) and the set of values. It has been also hypothesised that the current value set (and the contextual variables affecting it) will differ from the future value set (and the contextual variables impacting upon them).

Assessment of current and future values can assist educators in having a better idea of youth in their developmental phase of emerging adulthood. Generation $Y$ - as the current cohort in their emerging adulthood is called is known to be guided by and hold a very different set of values than previous generations of youth. Age-cohort analysis is particularly interesting as it is perceived to be one way of forecasting the near term future and can answer the question how institutions might change as a particular age group matures and gains status and power (Inayatullah et al. 2006).

The current paper therefore also contributes to informing institutional change by identifying how educational institutions assist students in their preparation for their future. It has been argued in recent literature (Trani and Holsworth 2010; Varblane and Mets 2010; Veroszta 2010) that education institutions and tertiary institutions in particular, in the enactment of their third mission have to have a responsible thinking about future generations. This mission has been articulated around this principle of social sustainability.

The methodological approach will draw upon a theoretical integration. This technique offers the possibility of piecing together theories in an attempt to clarify relationships between variables and ultimately increase variance explained by the integrated model where prior attempts were based solely on a single-level of explanation. Such an approach is deemed appropriate in studies which are exploratory in nature. There are generally three goals of theoretical integration (Rieckmann 2012; Muftic 2009). The first goal of integration is theory reduction when there are several concurrent theories competing against one another in an effort to essentially explain the same type of behaviour. Theory reduction is proposed as one 
way to decrease the number of theories on future orientation, allowing researchers to focus on a smaller number of theories. The second goal is to increase explained variance. The third goal of theoretical integration is theory development through the clarification and expansion of existing propositions and theoretical concepts (Muftic 2009). In the career development field, notions emerging in the post-industrial context have drawn attention to the necessity for personal malleability, resilience, and responsiveness to change in order to thrive in the contemporary world-ofwork. Concomitantly, there is a need to recognise that learning for and in the world of work requires theoretical perspectives that assume in their tenets the complexity of managing a career throughout the lifespan, extending from the age of schooling to post-retirement (Jasman and Mcllveen 2011).

\section{Literature review}

\section{Future orientation}

Future orientation (Nováky and Várnagy 2013; Hideg and Nováky 2010) is a way human thinking manifests itself, where thoughts are filled with preconceptions, imagination and expectations. It is perceived as an organic part of a person's general orientation and existence concerning events in their own environment, reasons, goals and consequences of their own actions (Hideg and Nováky 2010). It also entails the ability to plan for the future. Persons with high future orientation are characterized as pursuing their goals and engaging in daily planning of their activities, and preferring a problem-solving approach. Those who are highly future-oriented believe in their own ability to produce a desired effect and to lead a more active and self-determined life (Luszczynska, Gutiérrez-Doña, and Schwarzer 2005). Future orientation or the lack of it can enhance the well-being of societies, or conversely, make the entire society more vulnerable to changes (Hideg and Nováky 2010). This vulnerability especially permeates the handling of future uncertainty and risk management. A panel of contributing panellists in the Hungary 2025 compilation on the future prospects of the country concluded 
that although thinking about the future has become more widespread, future attitudes are more active and less frightening, and expectations concerning the future have improved considerably, there are still some lurking worsening trends (Hideg and Nováky 2010; Molnár and Vass 2013; Pál 2013). Future-oriented actions and concepts are very limited and a growing number of children are raised in families fearing the future (or future-shocked) (Hideg and Nováky 2010; Inayatullah et al. 2006). Ultimately, Hungarian society has become more vulnerable to imminent changes and challenges as consequences of the growing social inequality, economic stagnation and declining interest in democratic institutions. Hence, an increasingly wide strata of the population came to be affected by the unwelcome attitudes towards the future (Hideg and Nováky 2010).

Thinking about the future, setting up goals and aims is not solely determined by the mechanisms operating the individual, but by such personal dispositions as: the belief in a just world, the external-internal locus of control, and the mental health of the person. Beyond these factors, there is a wider range of social and economic shifts that affect the entity, which assert their effect through the agents of socialisation, and the above mentioned personal dispositions. Findings show that the members of the older generations place the time of realization of future plans closer, and these are more controllable thanks to the clearer verbalisation of the set goals in all walks of life (Mester 2012).

\section{Future orientation, optimism and subjective well-being}

Nurmi (1998) conceptualises the psychological process of future orientation as containing the three sequential elements of motivation, planning and evaluation. This planning activity requires a sense of optimism, which in return can be theorized to influence human behaviour through its effect on goal striving and motivation. As a disposition, it is expected that optimism has relevance across diverse situations. Optimism (Huppert and So 2013) is a generalized expectancy regarding future outcomes. Optimists, who hold positive expectancies for their future, should also harbour optimistic beliefs 
about their own ability to accomplish various goals. The pursuit lasts as long as optimistic beliefs about possible success (that is, self-efficacy) are sufficiently favourable.

Stabilising and enhancing the disposition of 'meaning and purpose' is especially important in the case of youth in emerging adulthood in transit from a relatively protective environment of formal or informal educational setting to the world of work which requires an entirely different set of attitudes and mindset. Youth have to face the continually changing and 'uncertain' world of work and their 'survival' depends on their adaptive capacity. Meaning and purpose, together with optimistic future planning constitute some important 'ingredients' of the feeling of subjective wellbeing (Eiroá Orosa 2012; Caunt et al. 2012; Diener and Chan 2011). Future generations' subjective well-being can be moderated through teaching them to discover and develop a sense of meaning and purpose that can function as an internal compass leading them through hard times (Jasman and McIlveen 2011).

Passive future orientation - that is waiting for the future to 'happen' can be replaced by a number of future oriented activities that can help individuals to actively shape their future. The most illustrious example of the active future orientation is the sustainability movement where governments alongside civil groups realising that 'we are just borrowing the future from our grandchildren' engage in preserving ecological as well as social environment (Molnár and Vass 2013).

\section{Values and norms}

Values are 'roadmaps' that define people's orientation, behaviour and judgement of situations, other people or attitudes. Values, based on their rank in importance, can represent the snapshot of not only individuals, but of entire societies as well. These values are arranged to a complex network of values, where, other than the relative rank of values, various value clusters can be detected (Ságvári 2011). This hierarchical structure is a characteristic feature of values, but not of norms and attitudes. Values are also connected 
to personal goals and, therefore, there is a close connection between motivations and values (Schwartz 2007). Personal value priorities serve as a guide for human decisions and action. Schwartz and Boehnke (2004) defined values as abstract beliefs about the desirable goals - ordered according to relative importance -, which guide individuals as they evaluate events, people and actions. Individuals' value priorities relate systematically to their personality traits, attitudes, and behaviour (Schwartz and Bilski 1987). Thus, values guide individual decision-making and motivate behaviour that is congruent with them (Schwartz 1992).

Norms and attitudes are related concepts which are often confusing and a brief clarification might be useful at this point (Ságvári 2011; Fukuyama 2001). Social norms are the generic rules of behaviour that a community observes and which is imposed upon its members. Any deviance from the norms are penalised by a system of sanctions (Merton 1968). The purpose of these norms is to make individuals' behaviour predictable, enabling cooperation between the members of the community. Attitudes, on the other hand, are individual and group reactions to certain objects, persons and situations, signifying a conscious or non-conscious acceptance of values carried by them. Attitudes are less abstract than values, that is, they are higher order components in human beings' inner cognitive structure. 'Our values organise and define our past, present and future. Our values orientate us, regulate the use of physical and mental energies, delineate our community belonging and social self' (Ságvári 2011) .

\section{Importance of family/environment/social norm in the formation of values of youth in emerging adulthood}

Recently Arnett (2007) proposed a stage that he calls emerging adulthood that encompasses roughly the ages of 18 to the late 20s and includes Super's (Brown and Lent 2004) transition stage and continues into his exploration stage. Emerging adulthood is a psychological stage that includes career development and can be described by five features that show how emerging adulthood differs from adolescence and young adulthood (which follows 
emerging adulthood): the age of identity explorations, the age of instability, the self-focused age, the age of feeling in-between, and the age of possibilities (Jensen and Arnett 2012; Arnett 2007; Arnett 2011; Cote 2006). The age of identity entails the making of crucial choices about work and love. In work, youth are choosing jobs that fit with how they see themselves, considering available opportunities.

This period is an age of instability in that young people may be changing jobs, or trying new areas of study in college or graduate school. This time of life can be seen as a self-focused age because individuals have few responsibilities and may be able to concentrate on career decisions and their potential effects. This period is referred to as the age of feeling inbetween because young people are likely to feel that they are neither adolescents nor adults, but on the road to becoming adults. In addition, it is called the age of possibilities or hopeful expectations because young people are likely to feel that their life will get better (Jensen and Arnett 2012), although country specific research shows that in Hungary the projection of hopes and hopeful thinking diminishes with age (Rédei, Kincses, and Jakobi 2011). This life stage is typically characterized by protracted identity exploration therefore the name: 'emerging adulthood' (Arnett 2011).

The impact of society on the individual's acquisition of values cannot be disregarded. Family provides the first and most secure environment for the young persons and as their socialisation takes place, they learn and become conditioned by the subsequent forms of educational institutions and other forms of community life. The impact of family bonds cannot be disregarded throughout an individual's life. In educational settings, the norms conveyed and taught offer the nearest strong bond to the family's set of ethical and moral values. When the young person enters the world of work, then a transition will take place between the norms and values conveyed by the educational institution and the values and norms that the workplace conveys and imposes on the individual (Jasman and Mcllveen 2011; Ságvári 2011), resulting in a degree of dissonance between values associated with these systems. All these norms are, of course, embedded in 
the higher rank societal values that guide the functioning of the larger community where the individual operates. With the shift in values, the rank in importance can be altered within individual communities but within the higher structure of society, as well. Furthermore, there are significant differences between the value systems and norms embraced by different generations within a higher stratum if society.

\section{Generation Y value systems}

The members of Generation Y were born between 1970 and the early 2000s. A typical trait of the group is the 'madness' for practicality and technology, because they have been brought up and used IT in their schooling (Pál 2013). Generation $Y$ have to develop a great degree of adaptive capacity to cope with the rapidly changing environmental variables as brought forth by the permeation of technological innovation in contemporary life. Immediate channelling of information is required of the individual, which is taken to the extreme in a way that what is not available on the internet is deemed to be inexistent (Tari 2010). These youth are labelled as 'hedonists', 'changemakers' (Pal 2013) 'on the outlook for social innovation', concomitantly 'disappointed' and 'disillusioned' in their civilian participation in polity and although interested in charity work and philanthropy, 'not going to the elections' (Print 2007; Lange et al. 2013). They are perceived to be supportive of the idea of and need for government, but invariably perceive governments as unresponsive, inflexible and ideologically driven by party ideologies and special interests (Print 2007).

In some other areas, though, this youth demonstrate a highlydeveloped sensitivity and responsiveness. Such areas are social change, social responsibility and environmental consciousness: in 2012, the Walden Report (Walden University 2012) on the responsiveness of international students to social change and environmental consciousness found that nearly all students believe they can make the world a better place by their actions and when economic conditions are bad, it is more important to be involved in social change than when economic conditions are good. 
This hybrid and complex attitude, coupled with the liquidification of societal norms and values (Bauman 2005) puts an enormous burden on youth striving to distinguish between what is morally sound and what is not. This generation has developed an entirely new vision of the world that researchers call happy midi-narrative (Tari 2010; Pál 2013; Ságvári 2011), a merge between two previous world visions, the metanarratives such as Christianity, having a well-defined set of principles about past, present and future, and the mini-narratives limited to short-sighted plans, such as what shall I do today? A characteristic feature of this happy midi-narrative era is that it conveys a future orientation, and albeit they tend to live for today and not plan on the long term, in their ego-centred approach are in the search for future expectations (Ságvári 2011).

This expectation has a significant impact on work-place settings, environment and how youth perceive meaning in and of work. With Gen Y representing the largest ever generational cohort to be joining the work context, career goals and daily expectations is of utmost importance. Studies demonstrate that particularly valued aspects are for organisations being fair, equitable, supportive, socially aware, and charitable. Also, for the organisation to offer training and graduate programmes and the opportunity for Gen Y employees to be involved in collaboration and organisational decision making, as well as to be recognised and valued for their contribution to the organisation (Luscombe, Lewis, and Biggs 2013). Gen $\mathrm{Y}$ employees also value being able to enjoy their work and to engage in challenging work which utilised their existing skills and training.

\section{Empowerment}

Empowerment is an umbrella construct that is widely used across a number of disciplines. It came to be discussed in the early 1960's and was originally conferring the meanings of, among others, having power, increasing self-worth (Bartunek and Spreitzer 2006). Since its original use, the concept has been extended to sociology, education, psychology, social work and finally, management disciplines, each of them applying it to describe distinct 
phenomena. It was in the education discipline that control over destiny, increasing knowledge, participation in decision making, enabling others, providing resources, taking responsibility were introduced (Bartunek and Spreitzer 2006) .

Welzel and Inglehart (2013) establish a human empowerment paradigm based on three pillars: existential, psychological and, finally, institutional empowerment. The combination of the three pillars result in the human empowerment:

'extent to which people are capable, motivated and entitled to exercise universal freedoms (civic agency). In providing universal competencies that make students global citizens, Universities play a central role in human empowerment, that is, students' faculty to act with a purpose; in other terms, their agency' (Sen 1999).

In the knowledge economy of the $21^{\text {st }}$ century, schools are accountable (Laine et al. 2008) for the ways that they prepare their students to become employable individuals. In their new function, they must be seen as embedded 'in' society instead of being an autonomous entity, or an institution 'of' society (Drucker 1993). Owing to the weakening efficiency of the 'mega state' in resolving social and economic matters, a new awakening of the citizenship is required, hence the recent increase in charity and volunteer work, especially in the West (Print 2007; Lange et al. 2013; Kennedy 2007). In the East of Europe, the need for community and citizenship is especially intense as this sector had been entirely damaged, if not totally destroyed according to some authors (Drucker 1993; Kennedy 2007). It will still take some time before the governments of these countries can completely carry out their tasks, as they had been entirely discredited in the past (Drucker 1993). In their new function of a major player of the knowledge economy, Universities face the responsibility to society at large to educate and train generations of not only fully employable, but active citizens that are fully operational globally (Kennedy 2007). Active citizenship education is especially important in societies where the practice of democratic participation is unsatisfactory or missing, like in the case of Central and Eastern Europe (Varblane and Mets 2010; Drucker 1993). 


\section{Role of higher education in shaping values/future orientation}

One of the most intriguing factors that societies across the globe have to cope with is the change in the value systems and education. Situated at the core of their transfer to youth in emerging adulthood, youth is more often than not incapable or incapacitated to follow and implement these changes as they occur (Kennedy 2007). Bauman (2005) warns us that society, leaving 'solid' and secure structures and paths is heading towards 'liquid' systems, in which former societal patterns and values are being 'liquidified'. Oftentimes, the pace of 'liquidification' is so fast, that patterns and values are not replaced by new ones. This transitional period challenges educational systems to a degree formerly unheard of.

It is widely accepted among scholars that schooling in itself strengthens future-orientation and related thinking (Inayatullah et al. 2006; Luthans, Stajkovic, and Ibrayeva 2000; Moscardo and Murphy 2011; Ng and Feldman 2007; Rubin 2013; Gaspar 2013; Laine et al. 2008) It has also been argued that the sustainable future of societies depend on the preparation of youth to encounter the uncertainties and insecurities of future by adequate skills and competencies (Nováky 2010).

Trani and Holsworth (2010) begin their book on tertiary education's new role with the basic premise that colleges and universities are in the midst of a major transformation that will redefine relationships to the broader community. Colleges and universities are serving as developers of social capital, providers of health care and as partners of regional development to engage their communities (Lange et al. 2013). This affiliation, coupled with the global movement toward a knowledge economy, formulates the indispensable university that has 'an ethical obligation to contribute to the common good' (Cuthill et al. 2010). One of the roles of the Business Schools' third mission being the education of future generations of youth that are empowered and engaged citizens. Jasman and Mcllveen (2011) highlighted in their paper that educational institutions can secure the empowerment of their students by maintaining a positive orientation to 
creating learning opportunities (commitment to life-long learning for all); and understanding the 'bigger' and more complex picture in order to take account of a wider range of factors and circumstances both within and beyond the immediate context.

Having identified and assessed the context and variables contributing to the formulation of future orientation of youth in emerging adulthood, the following research questions seem opportune and justified:

RQ1 How does the assessment of norms impact current and future values?

RQ2 How do current and future norms guiding current and future value sets differ when assessing them in the continuum?

RQ3 How do contextual variables predicting students' future orientation differ in their levels of significance?

\section{Predictors of future orientation - the model}

\section{Methodology}

The convenience sample of the survey consisted of a cohort of tourism and hospitality students of a Hungarian Business School, all 1 $1^{\text {st }}, 2^{\text {nd }}$, and $3^{\text {rd }}$ year students, having taken Entrepreneurship course in the framework of compulsory module. The paper-based auto fill-out survey, although directed at a more complex research objective, included a number of items addressing the above research questions and used different Likert-scales, each adjusted to the nature of the question. The survey has been administered by means of paper-based questionnaires and distributed and received from a totality of 212 students, all attending a specific lecture at a given survey time. The response rate was, in these special circumstances, $100 \%$. The distribution of females in the $N$ was $59.4 \%$, and the average age: 24.7 yrs. $75 \%$ of all students were, at the time of the survey, involved in active work, either in part-time employment, or in work placement, as a part of their course requirement. 


\section{Measures}

Measures have been developed based on relevant literature sources, in particular as follows: Pusztai et al. (2012); Nováky (2010); Veroszta (2010); Molnár and Vass (2013); and, following the advice of Luszczynska et al. (2005), only those with good psychometric properties were included. All measures included in the study had obtained satisfactory validity and reliability.

The construct of Current values has been measured by Section 1 of the questionnaire using terminal value measures developed by Rokeach (1973) and used by others in values research. The relevant section included the question: 'Please indicate how important you find the following values.' (1=very unimportant, $10=$ very important), and allowed for the assessment of 21 separate value items, ranging from 'family' to 'learning, education' and 'environmental protection'.

Current norms have been measured by section 2 where respondents were provided the question: 'In the constitution of your own set of values, please assess the influence of:', and 10 distinct choice items, typical options being: 'peer guidance', workplace norms, University values and norms'.

The construct Empowerment has been designed to consist of two subscales depending the institutional framework that is hypothesised to be at the origin of the empowerment. It has been derived from sections 17 and 18 of the questionnaire, based on the question: 'How satisfied are you with your University's delivery of the followings?' and 'How satisfied are you with your industrial practice delivering the followings: (if not attended, what are your expectations regarding) and included 6 items, amongst which: 'entrepreneurial competencies', 'responsible thinking/planning about the future'. Students' perceived level of satisfaction has been measured by a scale range from 1 for the least satisfied position to 100 for the most satisfied one.

The construct of Future interest has been measured by section 11: 'Please indicate your level of interest in the following entities' and included 8 items like: 'family', 'network of friends' 'workplace'. 
Future norms are conceptualised as the contextual variables that are perceived to have impact on the formation of interest in the future and have been measured by section 10 of the questionnaire and students indicated the importance of each of 10 norm items on the scale. Items were identical with the Current norms.

Future plans referred to the forward thinking of the students and the time frame in which they are making plans. They had to assess if they had any 'concretised idea of what they want to achieve in the next 5/10/15 years', answering yes (1) or no (2).

Future concern has been articulated as an attitudinal trait derived from optimism. In section 9, it asked the respondent to assess certain statements like: 'I control my future' and 'I am concerned about my future', the answer options being: 'not at all likely' (1) to 'wholly likely' (4).

\section{PLS-SEM}

For the estimation of our Predictors of Future Orientation model with empirical data, we use the PLS (Hair Jr et al. 2013) path modelling method and the SmartPLS 2.0 software application (Ringle, Wende, and Will 2005). The goal of predictive modelling used in the research has been to establish a theoretically grounded model that has high predictive power, and it differentiates itself from traditional CB-SEM modelling viewed as explanatory and confirmatory tools. Prediction relates to a situation where a theory leads to the forecast of some relevant outcome (Bagozzi and Yi 2012), its concept originating from an econometric perspective and is defined as 'the estimate of an outcome obtained by plugging specific values of the explanatory variables into an estimated model' (Woolridge 2003, 842).

Partial Least Squares (PLS) is commonly used in the social sciences, especially in business research disciplines. More specifically, information system researchers paid substantial attention to this technique due to its ability in modelling constructs in the case of small to medium samples and non-normality. PLS can perform factor analysis combined with path analysis 
and then the two methods can be used to estimate the significance (t-value) of each path (Hair et al. 2012).

Three advantages for researchers in using PLS seem to have been established: PLS works effectively with data from small sample sizes and a large number of parameters; PLS has a high computational and statistical efficiency; and PLS is flexible and versatile in dealing with problems that may be solved. PLS provides indicators to evaluate reliability and validity, for instance, item reliability, convergent validity, and discriminant validity. Furthermore, the goodness-of-fit can be evaluated in PLS. Several indicators are utilized to test the validation of the measurement model, model fit, and evaluation of the paths in the structural model. When PLS-Sem is applied, the structural model displays the concept with its key elements or constructs and cause-effect relationships with paths. Since the constructs are not directly observed, we need to specify a measurement model for each construct. To ensure the validity of our analysis, we adjusted the dataset by carrying out a missing value analysis and applied case wise deletion. All

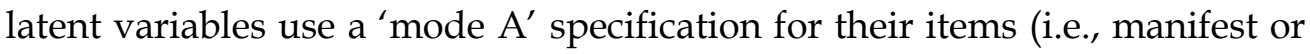
observed variables) in their measurement models, which is associated with reflective measurement (Hair et al. 2012).

\section{Measurement model analysis}

Measurement model parameter estimates and diagnostics provide evidence for the reliability and validity of the reflective construct measures. All multiitem scales exhibit composite reliability (rc) values well above the commonly suggested thresholds of .70 for rc and there is argument for the acceptance of less than .50 for the AVE (average variance extracted) values for discriminant validity.

Table 1 presents the results of the first iteration of the testing of the measurement model and how each observed variable relates to their construct. To analyse and evaluate the PLS path modelling results, reliability and validity we follow recommendations by Henseler et al. (2014) and Hair et al. (2013). 
A few interesting observations seem to be relevant when assessing the item loadings on the constructs. Item loading can explain the power by which the constructs are explained and as such, their ranking is informative of the views of the respondents in the matter. For example, higher item loadings mean that the respondents view those more prevalent in the formation of their opinions when responding to the items in the constructs. The current ranking of values can also serve as a justification or rebuttal of the perceived views on generation $Y$ values. Present values consist of items that demonstrate altruistic value: acting for the benefit of society in particular display a high factor loading. This is in line with the assessment of researchers saying that $\mathrm{Y}$ generation members 'want to be part of the solution and not just benefit from the actions of others' (Walden University 2014), resulting in an emerging sense of social responsibility, more powerful than other generations have (Pál 2013) . Education and learning is found to be the lowest ranking on their agenda.

In the case of the construct of Empowerment, the concern for these altruistic purposes as seen by the ranking of the items duly follows the pattern described above. Youth feel empowered by or display high expectation levels as to the experience delivered them in the workplace in the domains of social responsibility and civic engagement (Luscombe et al. 2013). Constructs such as Current norms, and Future Orientation context will be explained further below. 
Table 1. Outer path analysis

\begin{tabular}{|c|c|c|c|c|c|c|c|}
\hline Items loading on constructs & $\begin{array}{l}\text { Present } \\
\text { Values }\end{array}$ & $\begin{array}{l}\text { Present } \\
\text { Norms }\end{array}$ & $\begin{array}{l}\text { Em } \\
\text { power- } \\
\text { ment }\end{array}$ & $\begin{array}{l}\text { Future } \\
\text { Interest }\end{array}$ & $\begin{array}{l}\text { Future } \\
\text { Norms }\end{array}$ & $\begin{array}{l}\text { Future } \\
\text { Plans }\end{array}$ & $\begin{array}{l}\text { Future } \\
\text { Concern }\end{array}$ \\
\hline Acting for the benefit of society & .798 & & & & & & \\
\hline Job security & .776 & & & & & & \\
\hline Environmental conscientiousness & .761 & & & & & & \\
\hline Education, learning & .638 & & & & & & \\
\hline Workplace values guidance & & .806 & & & & & \\
\hline University guidance & & .780 & & & & & \\
\hline Societal norms & & .745 & & & & & \\
\hline Peer guidance & & 677 & & & & & \\
\hline Globalisation & & .670 & & & & & \\
\hline Responsibility for society (work) & & & .780 & & & & \\
\hline Active citizenship (work) & & & .762 & & & & \\
\hline Planning for future (university) & & & .733 & & & & \\
\hline Generation Y values (work) & & & .715 & & & & \\
\hline Entrepreneurial competencies (work) & & & .709 & & & & \\
\hline Responsibility for society (university) & & & .707 & & & & \\
\hline Active citizenship (university) & & & .703 & & & & \\
\hline Generation Y values (university) & & & 693 & & & & \\
\hline Planning for future (work) & & & 672 & & & & \\
\hline Practical knowledge (university) & & & 651 & & & & \\
\hline Entrepreneurial competencies (university) & & & 646 & & & & \\
\hline Practical knowledge (work) & & & .619 & & & & \\
\hline Interested in peers' future & & & & .772 & & & \\
\hline Interested in University's future & & & & .74 & & & \\
\hline Interested in family's future & & & & .713 & & & \\
\hline Societal norms guidance & & & & & .833 & & \\
\hline Workplace values guidance & & & & & .817 & & \\
\hline Uni guidance & & & & & .799 & & \\
\hline Family guidance & & & & & .729 & & \\
\hline Peer guidance & & & & & .719 & & \\
\hline Plans for $10 \mathrm{yrs}$ & & & & & & .848 & \\
\hline Plans for 15 yrs & & & & & & .772 & \\
\hline Plans for 5 yrs & & & & & & .670 & \\
\hline Not interested in the future & & & & & & & .946 \\
\hline Can hardly influence future & & & & & & & .595 \\
\hline
\end{tabular}

\section{Structural model}

Two main indicators can be used to evaluate the relationships between the paths in the PLS structural model: $R 2$ Coefficient of determination) values, and standardized path coefficient. $R 2$ values of the dependent variables represent the predictiveness of the theoretical model and standardized path coefficients indicate the strength of the relationships between the 
independent and dependent variables. Regarding measuring the power of R2, three levels were suggested: .670 substantial; .333 moderate; and .190 weak. Three levels of cut-off were adopted to assess the strength of path coefficient: . 2 weak; value between .2 and .5 is moderate; and more than .5 is strong.

The coefficient of determination $\left(R^{2}\right)$ is typically used as a criterion of predictive power (Hair et al. 2013). Table 2 presents the quality criteria of the structural model.

Table 2. Structural model overview

\begin{tabular}{lllll}
\hline & AVE & $\begin{array}{l}\text { Composite } \\
\text { Reliability }\end{array}$ & $\mathbf{R}^{2}$ & Cronbach $\boldsymbol{\alpha}$ \\
\hline Current Norms & .544 & .856 & 0 & .793 \\
Current Values & .559 & .834 & .167 & .734 \\
Empowerment & .491 & .920 & 0 & .907 \\
Future Norms & .610 & .886 & 0 & .840 \\
Future Interest & .550 & .786 & .301 & .628 \\
Plans & .588 & .809 & .115 & .643 \\
Concern & .625 & .760 & 0 & .466 \\
\hline
\end{tabular}

Evaluation of the prediction-oriented PLS path modelling method's results for the structural model centres on the $\mathrm{R}^{2}$ values. Figure 1 presents the structural model of the future orientation. The key target construct of the model, 'Future Interest', exhibits a moderately high $\mathrm{R}^{2}$ value of 301 (i.e., the Predictors of Future Orientation model explains overall Future Interest by $3.1 \%)$, whereas 'Current Values' are explained by $16.7 \% \quad\left(\mathrm{R}^{2}=.167\right)$, and 'Future Plans' by $11.5 \quad\left(\mathrm{R}^{2}=.115\right)$, respectively. The standardized path coefficients provide the basis for assessing the relative importance of relationships in the Predictors of Future Orientation model. Internal consistency displayed suggested minimum levels $(\alpha>65)$ for all latent constructs, except for 'Concern'. It is suggested that in exploratory phases of analyses and predictive modelling, Cronbach $\alpha$ values in the proximity of .5 be still accepted. 
Figure 1. Predictors of Future Orientation Model

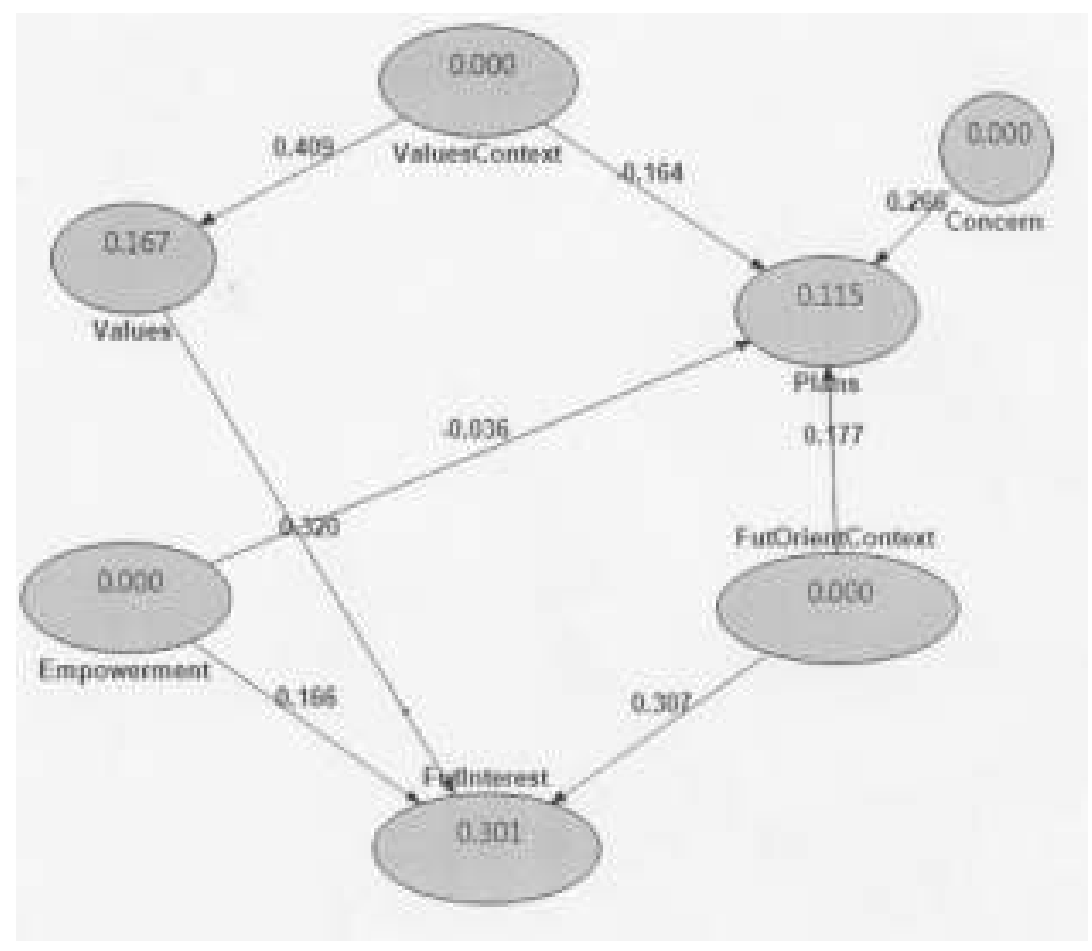

To test whether path coefficients differ significantly from zero, we calculated $t$-values using a bootstrapping routine (Henseler et al. 2014). The analysis substantiates that all relationships in the structural model have statistically significant estimates. 
Table 3. Significance testing results of the structural model path coefficients

\begin{tabular}{llll}
\hline Relationship & $\begin{array}{l}\text { Path } \\
\text { coefficient }\end{array}$ & Strength & t-value \\
\hline Current Norms -> Values & .409 & strong & $32.127 * * *$ \\
Current Norms -> Future Interest & .131 & weak & $14.6686 * * *$ \\
Current Norms -> Plans & -.164 & weak & $1.0746 * * *$ \\
Values -> Future Interest & .32 & moderate & $19.9546 * * *$ \\
Empowerment -> Future Interest & .165 & weak & $8.78 * * *$ \\
Empowerment -> Plans & -.036 & weak & $2.6369 * * *$ \\
Future Norms -> Future Interest & .307 & moderate & $24.0901 * * *$ \\
Future Norms -> Plans & .176 & weak & $12.8111 * * *$ \\
Concern -> Plans & .266 & moderate & $16.7464 * * *$ \\
\hline
\end{tabular}

Note: ${ }^{* * *}<.001$

\section{Discussion}

Predictive path analysis of the model provides some interesting insights into how future orientation is formulated. In particular, the relationship between norm guidance (context) and current and future value sets can be observed. Prediction by current norm guidance is more significant than future norm guidance suggesting that youth are less sure about constituents of the future norm guidance therefore cannot estimate with certainty how future guidance will influence future values or interests. What they are more certain about is how the current values shape the future value system, probably because it is perceived to be an extension of the current value system as this is tangible and known.

Empowerment is negatively correlated to plans, which can be explained by one or both of two processes: the perception of being empowered is at a low level at the onset, and therefore inversely impacts the formation of the future plans; or the formulation of plans is seen as a highly uncertain process which is not so much the result or a consequence of an empowered state, but the negative outcome of the impact by concern. Curiously, the state of being empowered positively contributes to the formation of future interest, while 
the effect of empowerment on the formation of future plans is inverse, that is, uncertain suggesting the complex nature of the phenomenon. Future interest, as an extension of the current value sets seem to be more stable and youth is capable of controlling its formation, whereas their agentic demeanour is less likely to act upon the formation of future plans.

By the same token, the formation of future plans is negatively related to the current value guidance norms or context. This goes hand in hand with the previous observation that plans are not foreseeable and palpable, and there is a great extent on insecurity and uncertainty in their formation. On the other hand, when thinking about future plans, it is much more the future value guidance norms that will have an eventual impact and thus shape the plans. Plans are definitely and significantly affected by future concern (observation resulting from the second highest path coefficient after current norm guidance impacting current value sets).

The findings of the survey inform our understanding of the difference students' assessment of how significantly their value sets are influenced by current and future norms. Table 4 provides information on the differences in ranking. For instance, whereas at present, still being under the protective umbrella of the University, but either already actively engaged in job hunting or working part-time and understanding the scarcity of employment, they are inevitably influenced by workplace norms. During the industrial training/practice they had a grasp on the importance of aligning with workplace values, or, as work and employment is a central focus of their orientation, they centre their activities and behaviour on projected workplace values. Workplace norms are not perceived to be such important in the 'Future Norms' as in the future, having found an employment, future young people expect to align more to the social norms. This will guide them through multiple roles and functions that they have to fulfil: active workers, parents, community members, citizens, etc. This cohort displays characteristics of norm acceptance that is distinctly different in the two timeframes: present and future. Other studies found that the highest percentage of hope was to be found at the age-group of 18-19, and they were the ones 
who trusted the most that their parents will support them in realizing their goals (Mester 2012). The 23-26 year-olds were the ones mostly motivated by the prospect of a job, and a family of their own, and to set aims related to these topics. Younger people predicted the time-of-realization of their goals concerning studies, job, and family to be a further date, in contrast with the older generations. These findings correlate to Iovu's (2014) findings who concluded that peer support was the most significant and family support the least significant variable in impacting future orientation and planning.

Table 4. Current and future norm rankings

\begin{tabular}{lllll}
\hline & $\begin{array}{l}\text { Current } \\
\text { Norm } \\
\text { ranking }\end{array}$ & $\begin{array}{l}\text { Item } \\
\text { Loading }\end{array}$ & $\begin{array}{l}\text { Future } \\
\text { Norm } \\
\text { ranking }\end{array}$ & $\begin{array}{l}\text { Item } \\
\text { Loading }\end{array}$ \\
\hline Workplace & 1 & .806 & 2 & .817 \\
values/guidance & & & & .799 \\
Uni values/guidance & 2 & .780 & 3 & .833 \\
Societal norms/guidance & 3 & .745 & 1 & .719 \\
Peer values/guidance & 4 & .677 & 5 & - \\
Global politics/guidance & 5 & .670 & - & .729 \\
Family values/guidance & - & - & 4 & \\
\hline
\end{tabular}

\section{Conclusion}

The research has provided timely and much-needed insight into how youth in emerging adulthood approach formation of future orientation. It also points out which contextual variables have significant impact on the process of forming future plans. The findings provide support for the explanatory utility of theoretically based investigations and, in particular, the importance of considering values systems and guiding norms predicting Gen Y individuals' work expectations. Findings can prove particularly informative for policy-makers in two distinct fields: education and employment. Education, responsible for the foundations for the sustainable future of societies, needs to prepare youth to successfully encounter the uncertainties and insecurities of future. Training for adequate skills and competencies is essential in this environment. In order to assess the performance of the 
sector, and intervene with adequate adjustments in policy and delivery of the policies, it is interesting to see how youth assess the educational environment in terms of empowerment. Policy-makers of employment on the other hand can gain insight from the findings in assessing how workplace practice guidance contributes to the constitution of current value sets and future interest.

In order to dissipate the concern (at times inherent) connected to the formation of future plans, it is recommended to encourage and expand the teaching to deal a lot with the future, to strengthen future orientation and respect of futures studies, in order to accelerate related social learning processes in Hungary (Hideg and Nováky 2010). Scholars in Hungary widely agree that power in future can be derived from characteristic adaptations and opportunity recognition instead of a pessimistic and retrograde vision of the world (Mester 2012; Pusztai et al. 2012; Nováky and Várnagy 2012).

\section{References}

Arnett, James J. 2007. "Socialization in emerging adulthood: From the family to the wider world, from socialization to self-socialization". In Handbook of socialization: Theory and research, edited by Joan E. Grusec and Paul D. Hastings, 208-231. New York: Guilford Press.

Arnett, James J. 2011. “Emerging adulthood(s): The cultural psychology of a new life stage." In Bridging cultural and developmental approaches to psychology: New Syntheses in theory, research and policy, edited by Lene Arnett Jensen, 255-275. New York: Oxford University Press.

Bartunek, Jean M., and Gretchen M. Spreitzer. 2006. “The Interdisciplinary Career of a Popular Construct Used in Management Empowerment in the Late 20th Century." Journal of Management Inquiry 15 (3): 255273.

Bauman, Zoltan. 2005. "A munkaetikától a fogyasztás esztétikájáig". Replika, 51-52: 221-238.

Brown, Steven D., and Robert W. Lent. 2004. Career Development and Counseling: Putting Theory and Research to Work. Hoboken: John Wiley \& Sons. 
Caunt, Benjamin S., John Franklin, Nina E. Brodaty, and Henry Brodaty. 2012. "Exploring the Causes of Subjective Well-Being: A Content Analysis of Peoples' Recipes for Long-Term Happiness." Journal of Happiness Studies 14 (2): 475-499.

Cote, Jerome. 2006. "Identity studies: How close are we to developing a social science of identity? - An appraisal of the field." Identity 6 (1): 325.

Diener, Ed, and Micaela Y. Chan. 2011. "Happy People Live Longer: Subjective Well-Being Contributes to Health and Longevity." Applied Psychology: Health and Well-Being 3 (1): 1-43.

Drucker, Peter. 1993. Post-Capitalist Society. New York: Harper Collins.

Eiroá Orosa, Francisco José. 2012. "Psychosocial Wellbeing in the Central and Eastern European Transition: An Overview and Systematic Bibliographic Review." International Journal of Psychology 48 (4): 437727.

Fukuyama, Francis. 2001. "Social capital, civil society and development." Third World Quarterly 22 (1): 7-2.

Hair, Joe F, Marko Sarstedt, Christian M Ringle, and Jeannette A Mena. 2012.

"An Assessment of the Use of Partial Least Squares Structural Equation Modeling in Marketing Research." Journal of the Academy of Marketing Science 40 (3): 414-433.

Hair Jr, Joseph F, G Tomas M Hult, Christian Ringle, and Marko Sarstedt. 2013. A Primer on Partial Least Squares Structural Equation Modeling (PLS-SEM). Thousand Oaks: Sage.

Henseler, Jörg, Theo K Dijkstra, Marko Sarstedt, Christian M Ringle, Adamantios Diamantopoulos, Detmar W Straub, David J Ketchen, Joseph F Hair, G Tomas M Hult, and Roger J Calantone. 2014. "Common Beliefs and Reality About PLS Comments on Rönkkö and Evermann (2013)." Organizational Research Methods 17 (2): 182-209.

Hideg, Éva, and Erzsébet Nováky. 2010. “Changing Attitudes to the Future in Hungary." Futures 42 (3): 230-36.

Huppert, Felicia A, and Timothy TC So. 2013. "Flourishing across Europe: Application of a New Conceptual Framework for Defining WellBeing." Social Indicators Research 110 (3): 837-61.

Inayatullah, Sohail, Marcus Bussey, Ivana Milojevic, eds. 2006. Neohumanist Educational Futures: Liberating the Pedagogical Intellect. Taipei: Tamkang University Press.

Iovu, Mihai-Bogdan. 2014. "How Do High School Seniors See Their Future?" Social Change Review 12 (1): 25-42 
Jasman, Anne, and Peter Mcllveen. 2011. "Educating for the Future and Complexity." On the Horizon 19 (2): 118-126.

Jensen, Lene Arnett, and Jeffrey Jensen Arnett. 2012. “Going Global: New Pathways for Adolescents and Emerging Adults in a Changing World." Journal of Social Issues 68 (3): 473-492.

Kennedy, Kerry J. 2007. “Student Constructions of 'active Citizenship': What Does Participation Mean to Students?" British Journal of Educational Studies 55 (3): 304-324.

Laine, Kari, Peter van der Sijde, Matti Lähdeniemi, and Jaakko Tarkkanen. 2008. "Higher Education Institutions and Innovation in the Knowledge Society." In Proceedings of the Rectors' Conference of Finnish Universities of Applied Sciences ARENE.

Lange, Dirk, Murray Print et al. 2013. Schools, Curriculum and Civic Education for Building Democratic Citizens. Vol. 2. Rotterdam: Sense Publishers.

Luscombe, Jenna, Ioni Lewis, and Herbert C Biggs. 2013. "Essential Elements for Recruitment and Retention: Generation Y." Education+ Training 55 (3): 272-279.

Luszczynska, Aleksandra, Benicio Gutiérrez-Doña, and Ralf Schwarzer. 2005. "General Self-Efficacy in Various Domains of Human Functioning: Evidence from Five Countries." International Journal of Psychology 40 (2): 80-89.

Luthans, Fred, Alexander D Stajkovic, and Elina Ibrayeva. 200. "Environmental and Psychological Challenges Facing Entrepreneurial Development in Transitional Economies." Journal of World Business 35 (1): 95-111.

Mead, Margaret. 1978. Culture and Commitment. The New Relationships between the Generations in the 1970s. New York: Columbia University Press.

Merton, Robert King. 1968. Social Theory and Social Structure. New York: The Free Press.

Mester, Dolli. 2012. "Impacts of Family Socialization on Young Adults' Future-Oriented Goals." Transylvanian Journal of Psychology 13 (2): 164-190.

Molnár, Péter, and Zoltan Vass. 2013. "Pessimistic Futures Generation for Pessimistic Future Generations? The Youth Has the Future but the Older Has the Authority." Futures 45: 55-61.

Moscardo, Gianna, and Laurie Murphy. 2011. "Toward Values Education in Tourism: The Challenge of Measuring the Values." Journal of Teaching in Travel \& Tourism 11 (1): 76-93. 
Muftic, Lisa R. 2009. “Macro-Micro Theoretical Integration: An Unexplored Theoretical Frontier." Journal of Theoretical \& Philosophical Criminology 1 (2): 22-71.

Ng, Thomas WH, and Daniel C Feldman. 2007. "The School-to-Work Transition: A Role Identity Perspective." Journal of Vocational Behavior 71 (1): 114-134.

Nováky, Erzsébet, and Réka Várnagy. 2013. “Discovering Our Futures-a Hungarian Example." Futures 45: 45-54.

Nurmi, Juhani M. 1998. "How do Adolescents see and create their future." In Proceedings of the 6th Biennial Conference of the European Association for Research on Adolescence, Budapest, 1998, 105-125. Budapest: Corvinus University of Budapest.

Pál, Emese. 2013. The Generation 'Z.' Pécs: Pecs University Press.

Print, Murray. 2007. "Citizenship Education and Youth Participation in Democracy." British Journal of Educational Studies 55 (3): 325-345.

Pusztai, Gabriella, Sergiu Baltatescu, Klára Kovács, and Szilvia Barta. 2012. "Social Capital and Student Well-Being in Higher Education." HERJ Hungarian Educational Research Journal 2 (4): 54.

Rédei, Mária, Áron Kincses, and Ákos Jakobi. 2011. "The World Seen by Hungarian Students: A Mental Map Analysis." Hungarian Geographical Bulletin 60 (2): 135-159.

Rieckmann, Marco. 2012. "Future-Oriented Higher Education: Which Key Competencies Should Be Fostered through University Teaching and Learning?" Futures 44 (2): 127-135.

Ringle, Christian M., Stephan Wende and Andreas Will. 2005. SmartPLS 2. Hamburg, www.smartpls.de.

Rokeach, Milton. 1973. Beliefs, attitudes and values. San Francisco: Jossey-Bass. Ságvári, Bence. 2011. Kultúra és Gazdaság. Budapest: ELTE.

Schwartz, Shalom H. 2007. "Value orientations: measurement, antecedents and consequences across nations". In Measuring Attitudes CrossNationally. Lessons from the European Social Survey, edited by Robert Jowell and Eva Roberts, 169-200. London: Sage.

Schwartz, Shalom H. 1992. "Universals in the content and structure of values: Theory and empirical tests in 20 countries". In Advances in experimental social psychology, edited by M. Zanna, 1-65. New York: Academic Press.

Schwartz, Shalom H. and Karl Boehnke. 2004. "Evaluating the structure of human values with confirmatory factor analysis." Journal of Research in Personality 38 (3): 230-255. 
Schwartz, Shalom. H. and William Bilsky. 1987. "Toward a psychological structure of human values". Journal of Personality and Social Psychology 53 (3): 550-562.

Tari, Annamaria. 2010. Y Generáció. Budapest: Jaffa.

Trani, Edward P. and Holsworth, Robert, D. 2010. The indispensable university: higher education, economic development and the knowledge economy. Lanham, Md.: Rowman \& Littlefield.

Varblane, Uwe and Thomas Mets. 2010. "Entrepreneurship education in the higher education institutions (HEIs) of post-communist European countries." Journal of Enterprising Communities: People and Places in the Global Economy 4(3): 204-219.

Veroszta, Zsuzsanna. 2010. “Felsőoktatási Értékek-Hallgatói Szemmel. A Felsőoktatás Küldetésére Vonatkozó Hallgatói Értékstruktúrák Feltárása. (Higher Education Values-from the Aspect of University Students Reveal of University Student Value Structures Concerning the Mission of Higher Education.)". Ph.D. dissertation. Budapest ELTE.

Walden University, LLC. 2012. “Walden Students' Perceptions about Social Change." www.waldenU.edu/impactreport.

Welzel, Christian, and Ronald Inglehart. 2013. "Evolution, Empowerment and Emancipation: How Societies Ascend the Utility Ladder of Freedoms." World Values Research 6(1): 1-45.

Wooldridge, James M. 2003. Introductory Econometrics. A Modern Approach. Mason, $\mathrm{OH}$ : Thomson South-Western. 